\title{
A Chlorotic Spot Disease on Calla Lilies (Zantedeschia spp.) Is Caused by a Tospovirus Serologically but Distantly Related to Watermelon silver mottle virus
}

C. C. Chen, Department of Plant Protection, Taichung District Agricultural Improvement Station, Changhua, Taiwan; T. C. Chen, Y. H. Lin, and S. D. Yeh, Department of Plant Pathology, National Chung Hsing University, Taichung, 40227 Taiwan; and H. T. Hsu, Floral and Nursery Plants Research Unit, U.S. Department of Agriculture, Agricultural Research Service, Beltsville, MD 20705, USA

\begin{abstract}
Chen, C. C., Chen, T. C., Lin, Y. H., Yeh, S. D., and Hsu, H. T. 2005. A chlorotic spot disease on calla lilies (Zantedeschia spp.) is caused by a tospovirus serologically but distantly related to Watermelon silver mottle virus. Plant Dis. 89:440-445.

A new tospovirus, Calla lily chlorotic spot virus (CCSV), was isolated from calla lilies (Zantedeschia spp.) in Taiwan. Chlorotic spots, ranging from light green to yellow, appear on the middle leaves of the affected plants. Virions measuring 75 to $105 \mathrm{~nm}$, similar in size to tospovirus particles, were present in crude extracts and ultrathin sections of diseased leaves. Of 35 plant species inoculated mechanically, 24, including wax gourd (Benincasa hispida) and zucchini squash (Cucurbita pepo), were susceptible to the virus. CCSV was transmitted from infected wax gourd by Thrips palmi to healthy wax gourd and zucchini squash. The virus was weakly related to Watermelon silver mottle virus (WSMoV) in enzyme-linked immunosorbent assay (ELISA) and western blot tests. WSMoV-specific $\mathrm{N}$ gene primers, however, failed to produce DNA fragments from total RNA extracts of CCSV-infected plants in reverse transcriptionpolymerase chain reaction (RT-PCR). Results of RT-PCR show that the conserved regions of the $\mathrm{L}$ genes of tospoviruses are present in CCSV.
\end{abstract}

Additional keywords: electron microscopy, insect vector, serology

Calla lilies (Zantedeschia spp.) are members of the family Araceae that were introduced into Taiwan in the 1980s for cut flower production. They are grown primarily in the central part of Taiwan. Production of calla lilies has become an important part of the floral industry for both domestic and overseas markets. About $10 \%$ of the crop is exported to Japan and Hong Kong; the remaining $90 \%$ is consumed domestically. Calla lilies are highly sus-

Corresponding author: H. T. Hsu

E-mail: hsuht@ba.ars.usda.gov

Cooperative investigation, Taichung District Agricultural Improvement Station, Changhua, National Chung Hsing University, Taichung, and United States Department of Agriculture, Beltsville, MD.

Mention of a trade name, proprietary product, or specific equipment does not constitute a guarantee or warranty by the U.S. Department of Agriculture and does not imply approval to the exclusive of other products that may also be suitable.

Accepted for publication 10 December 2004.

DOI: 10.1094/PD-89-0440

This article is in the public domain and not copyrightable. It may be freely reprinted with customary crediting of the source. The American Phytopathological Society, 2005. ceptible to several viruses, including Tomato spotted wilt virus (TSWV) (26), Turnip mosaic virus (TuMV) $(3,4)$, Zantedeschia mosaic virus (ZaMV) (2), Zantedeschia mild mosaic virus (ZaMMV) (13), Konjac mosaic virus $(15,18), D a-$ sheen mosaic virus (DsMV) (15), and Carnation mottle virus (CarMV) (5).

In 2001, a field survey of virus diseases in calla lilies was conducted in central Taiwan. Plants with symptoms resembling viral infection were brought to Taichung District Agricultural Improvement Station (TDAIS) for diagnosis. They were found to be infected with one or more viruses, including CarMV, Cucumber mosaic virus (CMV), DsMV, TuMV, ZaMV, and ZaMMV, when tested by enzyme-linked immunosorbent assay (ELISA). Chlorotic spots were found on some of these symptomatic plants. Crude leaf extracts were prepared and tested by ELISA with antisera prepared to Watermelon silver mottle virus (WSMoV) and TSWV (23). None of the extracts reacted with TSWV antiserum, but some reacted with WSMoV antiserum. Electron microscopy revealed the presence of tospovirus-like particles, measuring 75 to $105 \mathrm{~nm}$ in diameter, in negatively stained preparations of crude sap extracted from leaves of diseased calla lilies that reacted positively with WSMoV antiserum in ELISA. Similar particles were also observed in ultrathin sections of embedded leaf tissues of the diseased plants. Among tospoviruses, only TSWV has been reported to occur in calla lilies (26). The purpose of the present study was to characterize biological and immunological properties and ultrastructure of this previously unknown causal agent.

\section{MATERIALS AND METHODS}

Virus sources. Calla lily chlorotic spot virus (CCSV) cultures used in current studies were isolated in May 2001 from naturally infected calla lilies showing chlorotic spots on leaves (Fig. 1A and B). The virus was transferred to Nicotiana benthamiana Domin. by mechanical inoculation using an extract of diseased leaves prepared in inoculation buffer $(10$ $\mathrm{mM}$ sodium phosphate, $10 \mathrm{mM}$ sodium sulfite, $\mathrm{pH}$ 7.0). A virus culture was established from infected leaf tissues of $N$. benthamiana, followed by two successive single-lesion isolations on Chenopodium quinoa Willd., and maintained in $N$. benthamiana. The virus cultures in infected $N$. benthamiana leaves were also stored in liquid nitrogen.

TSWV was provided by R. Provvidenti of New York State Agricultural Experiment Station, Geneva; Groundnut ringspot virus (GRSV) by D. Gonsalves, New York State Agricultural Experiment Station (17); and Impatiens necrotic spot virus (INSV) by J. Moyer, North Carolina State University, Raleigh (14). WSMoV was isolated from watermelon in Taiwan (24), and Peanut chlorotic fan-spot virus (PCFV) from peanut in Taiwan (8). All virus preparations used in the studies were prepared from infected $N$. benthamiana.

Host range. Thirty-five plant species were mechanically inoculated with CCSV. Inoculated plants were kept in a screenhouse for 4 weeks for observation of symptom development. Inoculated plants, both symptomatic and asymptomatic, were tested by ELISA using the WSMoV antiserum (24). Symptomatic plants were also checked by electron microscopy (EM) for the presence of tospovirus-like particles in 
leaf dips. The infectivity assay was, however, used to confirm the absence of virus in asymptomatic plants.

Thrips and transmission. Healthy colonies of Thrips palmi Karny were caged on eggplant (Solanum melongena L.) and maintained in a $26^{\circ} \mathrm{C}$ insectary with a 12 -h $(6,000 \mathrm{~lx})$ lighting period. Plants were grown in clay pots with a layer $(0.2 \mathrm{~cm})$ of sand on top of soil media. Nymphs were given a 4-h acquisition access feeding on wax gourd (Benincasa hispida (Thunb.) Cogn.) infected with CCSV. They were then allowed to feed on healthy wax gourd or zucchini squash (Cucurbita pepo L. var. Zucchini) seedlings at a density of 10 insects per plant. At the end of 3-day inoculation feedings, plants were sprayed once with the insecticide Imidacloprid SL (Bayer Crop Science, Rhein, Germany), $0.75 \mathrm{ml} /$ liter, and kept in a greenhouse. Thereafter, the insecticide was applied weekly for 4 weeks during observation of symptom development. At the end of the observation period, all plants were tested by infectivity assay on $C$. quinoa and by ELISA using WSMoV antiserum. Symptomatic plants also were confirmed by EM for the presence of tospovirus-like particles.

EM. Formvar-coated, carbon-stabilized copper grids (300 mesh) were floated for 3 min on one drop of crude sap extracted from diseased leaf tissues. Samples were then stained with $2 \%$ uranyl acetate for 10 $\mathrm{s}$ and examined with a JOEL $200 \mathrm{CX}$ electron microscope (JOEL Ltd., Tokyo, Japan). For ultrathin sections, leaf tissues of diseased calla lilies or inoculated $N$. benthamiana showing distinct symptoms were cut into small pieces, fixed in $2 \%$ glutaraldehyde in $0.1 \mathrm{M}$ phosphate solution $(\mathrm{pH}$ 7.0) for $4 \mathrm{~h}$, then in $2.5 \%$ osmium tetroxide at room temperature for an additional 2 $\mathrm{h}$ before being dehydrated in a graded series of ethanol. Samples were embedded in LR white resin. Ultrathin sections were stained with $2 \%$ uranyl acetate followed by $2 \%$ lead acetate, and examined in the electron microscope.

Indirect ELISA. Rabbit antisera individually prepared to INSV, TSWV, WSMoV, PCFV (8), TuMV (4), ZaMMV (13), ZaMV, DsMV (2), CMV (4), and CarMV (5) in previous investigations were used. An indirect ELISA procedure previously reported (22) was modified. Costar Clear Polystyrene 96-well plates were coated with crude extracts diluted 20-fold in coating buffer $(0.05 \mathrm{M}$ sodium carbonate, $\mathrm{pH}$ 9.6, containing $0.01 \%$ sodium azide). Antisera at 1:4,000 dilution in conjugate buffer (phosphate-buffered saline containing $0.05 \%$ Tween $20,2 \%$ polyvinylpyrrolidone- 40 , and $0.2 \%$ ovalbumin) were used. Goat anti-rabbit immunoglobulin $\mathrm{G}$ (IgG) alkaline phosphatase (AP) conjugate (Kirkegaard \& Perry Laboratories, Gaithersburg, MD) was diluted to 1:5,000 in conjugate buffer. Substrate solu- tion was prepared by dissolving $p$ nitrophenyl phosphate tablets (Sigma Chemical, St. Louis, MO) in substrate buffer $(97 \mathrm{ml}$ of diethanolamine and $0.2 \mathrm{~g}$ of sodium azide per liter, $\mathrm{pH}$ 9.8) to a final concentration of $1 \mathrm{mg} / \mathrm{ml}$. Absorbance at $405 \mathrm{~nm}\left(A_{405 \mathrm{~nm}}\right)$ was recorded using an ELx800 universal microplate reader (BioTek Instruments, Winooski, VT) $30 \mathrm{~min}$ after the addition of substrate.

Western blot. Western blot analysis was performed according to a method previously described (11). Crude antigens (5:1) extracted from leaf tissues of $N$. benthamiana infected with individual tospoviruses $(20 \mathrm{mg}$ of tissue in $1 \mathrm{ml}$ of dissociation buffer containing $50 \mathrm{mM}$ Tris- $\mathrm{HCl}$, $\mathrm{pH} 6.8,100 \mathrm{mM}$ dithiothreitol, $2 \%$ sodium
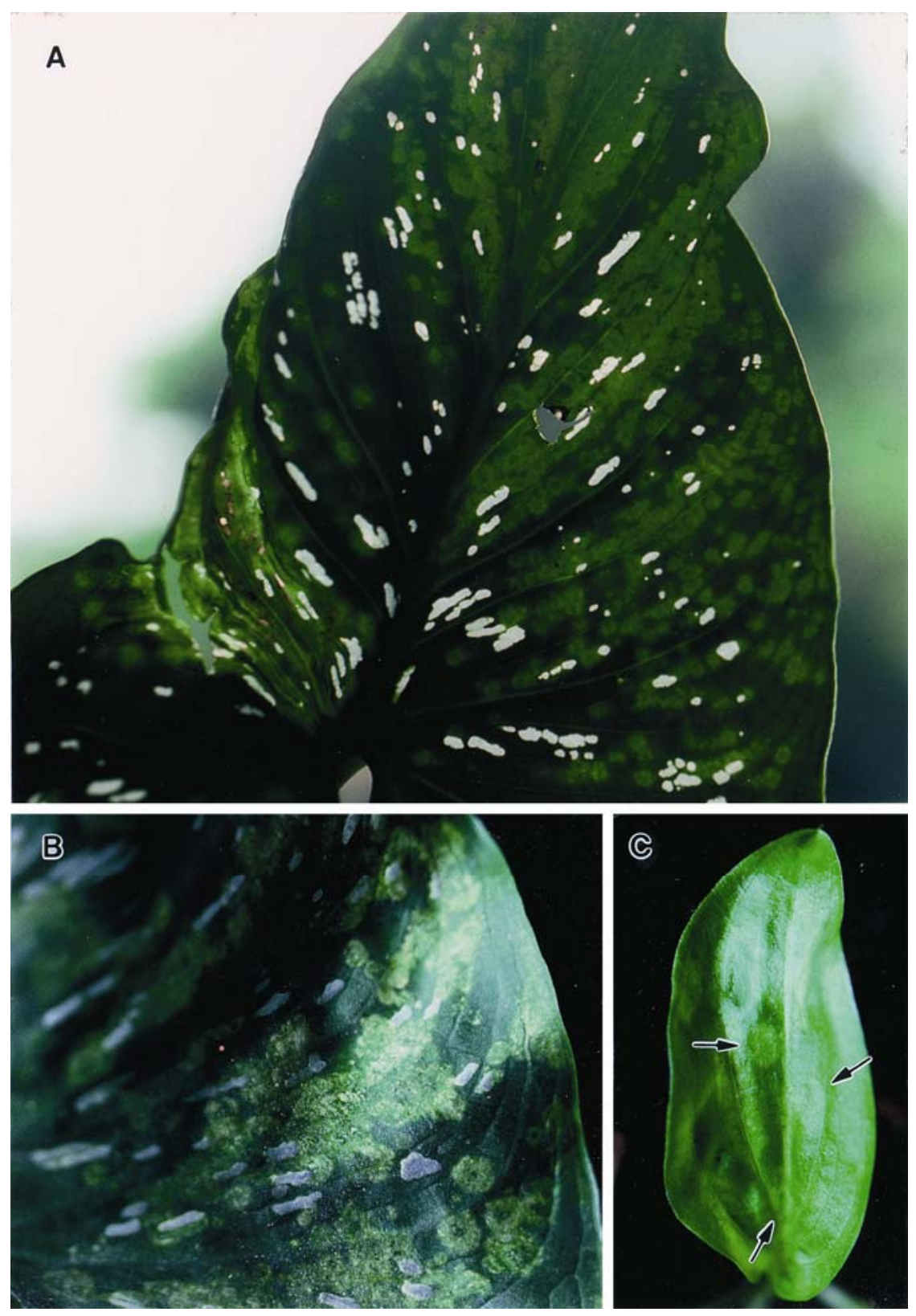

Fig. 1. Symptoms induced by Calla lily chlorotic spot virus on calla lily leaves. Chlorotic or yellow spots about 2 to $3 \mathrm{~mm}$ in diameter radiate from midrib toward the edge of the leaf. Symptoms on $\mathbf{A}$, upper surface and $\mathbf{B}$, lower surface of a leaf from field-infected plants. C, Chlorotic spots (arrows) on

an inoculated leaf of calla lily.

dodecyl sulfate [SDS], $0.1 \%$ bromophenol blue, and $10 \%$ glycerol) were loaded onto a $12 \%$ polyacrylamide gel, fractionated, and transferred to nitrocellulose membranes. Subsequently, each membrane was incubated with antisera at 1:4,000 dilution, followed by AP-conjugated goat antirabbit $\operatorname{IgG}(1: 5,000$ dilution) and chromogenic substrates (nitroblue tetrazolium/5-bromo-4-chloro-3-indolyl phosphate paratoluidine salt in $100 \mathrm{mM} \mathrm{NaCl}$, $5 \mathrm{mM} \mathrm{MgCl}$, and $100 \mathrm{mM}$ Tris- $\mathrm{HCl}, \mathrm{pH}$ 9.5). Extracts from leaves of uninfected plants were used as controls.

Reverse transcription-polymerase chain reaction (RT-PCR). The forward and reverse degenerate primer pairs $\mathrm{gL}$

\section{7 (5'-CCTTTAACAGT (A/T/G) GAA-}


ACAT- $\left.3^{\prime}\right)$ and $\mathrm{gL} \quad 4435 \mathrm{c}$ (5'-CAT (A/T/G)GC(A/G)CAAGA(A/G)TG(A/G)T $\left.\mathrm{A}(\mathrm{A} / \mathrm{G}) \mathrm{ACAGA}-3^{\prime}\right)$ published previously for amplification of the conserved region of the L genes of tospoviruses (7), and the specific primers WN2645K (5'-GGGTACCCACTTCCAAAGAAGTGCTGGGCTT-3') and WN3469cKS (5'-GGCATGCATGTCTAACGTTAAGCAGCTCACA$3^{\prime}$ ) for amplification of WSMoV N gene (6) were used in RT-PCR. Total RNAs were individually extracted from infected plants using a commercial kit (ULTRSPEC, Biotecx Co., Houston, TX) according to the manufacturer's protocol. Reverse transcription and PCR were carried out with 1 to $2 \mu \mathrm{g}$ of total RNA in a reaction mixture of $50 \mu$ l (Fast-Run RT-PCR, Proteck, Taipei, Taiwan) as previously described (7).

Cloning and sequence analyses. The amplified DNA products were cloned into TA cloning vector (Invitrogen, Carlsbad, CA) according to the instructions provided by the manufacturer. DNA fragments were ligated with pCR2.1-TOPO vector (Invitrogen) and cloned by One Shot transformation reaction using E. coli $\mathrm{TOP} 10 \mathrm{~F}^{\prime}$

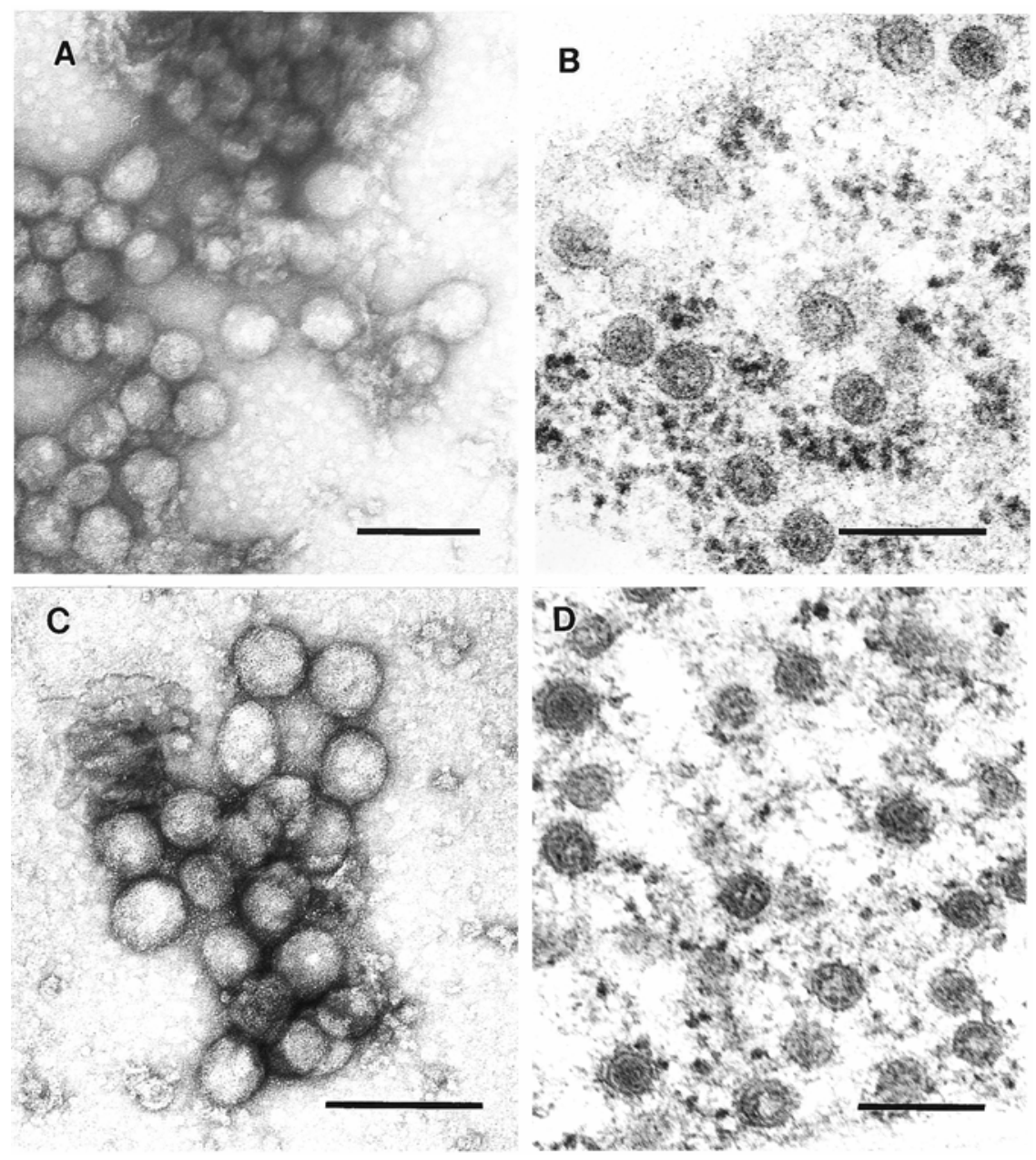

Fig. 2. Electron micrographs of virions of Calla lily chlorotic spot virus (CCSV). Virions, A, in leaf dip stained in $2 \%$ uranyl acetate, and $\mathbf{B}$, in an ultrathin section of leaves stained in $2 \%$ uranyl acetate and $2 \%$ lead acetate from CCSV-infected calla lilies. Virions, $\mathbf{C}$, in leaf dip and $\mathbf{D}$, in cytoplasm of ultrathin sections of leaf tissues of a CCSV-infected Nicotiana benthamiana. Bars represent $100 \mathrm{~nm}$. showed that about $85 \%$ of the collected samples were infected with one or more viruses, including CarMV, CMV, DsMV, TuMV, ZaMV, and ZaMMV (data not presented). Of the plants collected in the survey, 11 showing chlorotic spot symptoms reacted positively in ELISA with WSMoV antiserum. Nine of them were also found to be infected with TuMV or ZaMV. EM examination of the two plants revealed the presence of tospovirus-like particles in the crude leaf extracts. They were used for establishment of virus cultures.

Symptoms and host range. Disease symptoms on naturally infected calla lilies appeared mostly on middle leaves of plants. Symptoms were mostly chlorosis with a few yellow spots about $2 \mathrm{~mm}$ in diameter radiating from midrib toward the edge of the leaves (Fig. 1A and B). Inoculation of healthy calla lily seedlings with inocula prepared from CCSV-infected $N$. benthamiana produced chlorotic spots similar to those on naturally infected plants (Fig. 1C). Larger calla lily plants were, however, not susceptible to mechanical inoculation.

Of a total of 35 plant species mechanically inoculated, 24 species were susceptible to the virus. Systemic invasion of CCSV was observed in Benincasa hispida, Citrullus lanatus (Thunb.) Matsum. \& Nakai, Cucumis melo L., C. metuliferus Vivaldi, C. sativas L., Cucurbita pepo cv. Field pumpkin, Gomphrena globosa subsp. lanatus (Thunb.), Lagenaria siceraria (Molina) Standl., Luffa cylindrical (L.) M. Roem., $N$. benthamiana, $N$. tabacum L. cv. Hicks, and Zantedeschia sp. Symptoms on systemic hosts were mostly light yellowgreen spots on leaves. Local lesions were found on inoculated leaves of Capsicum annuum L., Chenopodium album L., C. quinoa, Datura stramonium L., N. glutinosa L., Nicotiana hybrida L., N. rustica L., N. tabacum cv. White Burley, Plantago major L., Solanum melongena L., Spathiphyllum kochi, and Syngonium podophyllum Schott. EM examination showed that tospovirus-like particles were present in crude sap of symptomatic plants, whether systemic or local lesion hosts. Infections were also confirmed by positive reaction to WSMoV antiserum in ELISA.

Amaranthus mangostanus L. form ruber, Brassica chinensis, Capsicum annuum red pepper, Catharanthus roseus (L.) G. Don, Celosia argentea L., Dianthus barbatus L., Phaseolus vulgaris L., Pisum sativum L., Lycopersicon esculentum Mill., Vigna unguiculata (L.) Walp., and Zinnia elegans Jacq. were not infected when inoculated with CCSV as determined by symptom expression, ELISA, and infectivity assay on C. quinoa.

Thrips transmission. Of a total of 12 wax gourd seedlings inoculated with thrips previously fed on virus-infected plants in two experiments, four became diseased, 
showing chlorosis and crinkling on leaves. A leaf dip assay by EM showed the presence of tospovirus-like particles in diseased plants. In zucchini squash, three out of 10 inoculated plants in two experiments exhibited yellowing on leaves. Leaf dip examination by EM also revealed the presence of tospovirus-like particles. Crude extracts from leaves of the symptomatic plants tested positive with WSMoV antiserum in ELISA, indicating that Thrips palmi is able to transmit CCSV.

EM. Particles measuring 70 to $105 \mathrm{~nm}$ in diameter were found in the leaf dips prepared from infected calla lilies (Fig. 2A). Similar-sized particles were present in the cytoplasm, but not in nuclei in ultrathin sections of leaf tissues of symptomatic calla lilies (Fig. 2B). Tospovirus-like particles were also observed in extracts and ultrathin sections of infected $N$. benthamiana leaf tissues (Figs. 2C and D).

Serological reactions. Positive results were observed in indirect ELISA of crude extracts prepared from CCSV- and WSMoV-infected $N$. benthamiana (Fig. $3 \mathrm{~A}$ ). The $A_{405 \mathrm{~nm}}$ reading of homologous reaction was about three times that of heterologous reaction. CCSV extracted from diseased $N$. benthamiana did not react with antiserum prepared to TSWV, INSV, or PCFV. Similar serological relationships were also observed in immunoblot analysis using WSMoV antiserum. The antiserum reacted with antigens strongly in homologous reactions but weakly in heterologous reactions (Fig. 3B). A protein, presumably the nucleocapsid protein (NP) of CCSV, about $31 \mathrm{kDa}$, similar to that of WSMoV, was observed in the blot (Fig. 3B). As expected, the WSMoV antiserum did not react with TSWV, INSV, PCFV, or host plant antigen.

RT-PCR and sequence comparison. A DNA fragment of $0.8 \mathrm{kbp}$ was amplified by RT-PCR from total RNA extracted from CCSV-infected plants using degenerate primer pairs gL3637/gL4435 designed from the conserved regions of the $\mathrm{L}$ genes of tospoviruses (Fig. 4A). As expected, a $0.8-\mathrm{kbp}$ DNA product was also obtained from the total RNA extracted from plants infected with WSMoV, TSWV, or INSV (Fig. 4A). No products were obtained when total RNA from healthy plants were tested in the reaction. The amplified DNA product of CCSV was cloned, and the sequence was compared with the conserved region of the $\mathrm{L}$ proteins of WSMoV, TSWV, INSV, PBNV, MYSV, and TYFRV (Fig. 5). CCSV shares 65.2 to $92.9 \%$ and 76.4 to $96.6 \%$ identities and similarities, respectively, with the conserved regions of the $\mathrm{L}$ proteins of other tospoviruses (Table 1). No DNA products were obtained from the total RNA extracted from CCSV-, TSWV-, or INSVinfected or healthy plants in RT-PCR using the specific primers specific for the $\mathrm{N}$ gene of WSMoV (Fig. 4B). A DNA
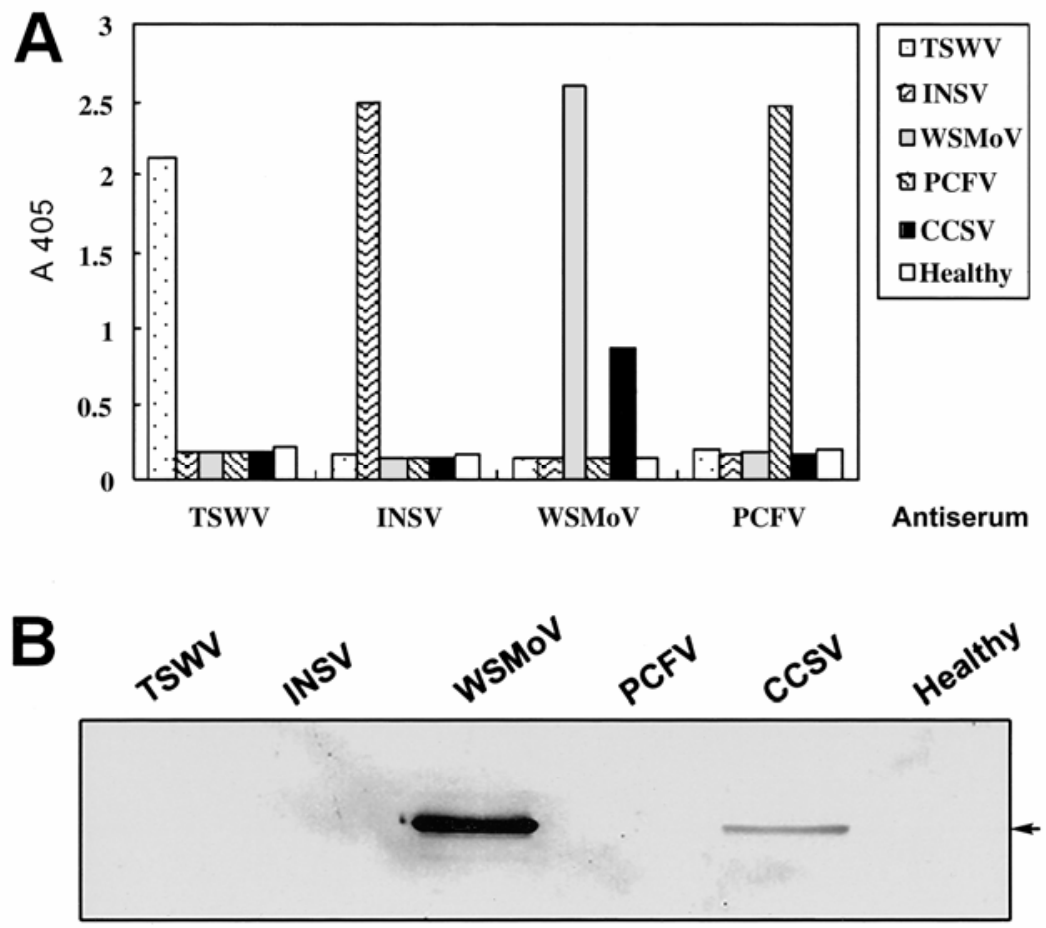

Fig. 3. A, Enzyme-linked immunosorbent assay and B, immunoblot analysis of Calla lily chlorotic spot virus (CCSV). Leaf extracts were prepared from Tomato spotted wilt virus (TSWV), Impatiens necrotic spot virus (INSV), Peanut chlorotic fan-spot virus (PCFV), Watermelon silver mottle virus (WSMoV), and CCSV-infected or healthy Nicotiana benthamiana. A, Following incubation with leaf extract, microfilter plates were individually incubated with TSWV-, INSV-, WSMoV-, or PCFVspecific antiserum and alkaline phosphatase-labeled goat anti-rabbit immunoglobulins. Absorbance at $405 \mathrm{~nm}$ was recorded $30 \mathrm{~min}$ after the addition of substrates. B, Nitrocellulose membrane, after protein blotting, was subsequently incubated with WSMoV-specific antiserum, alkaline phosphatase-labeled goat anti-rabbit immunoglobulins, and chromogenic substrates.
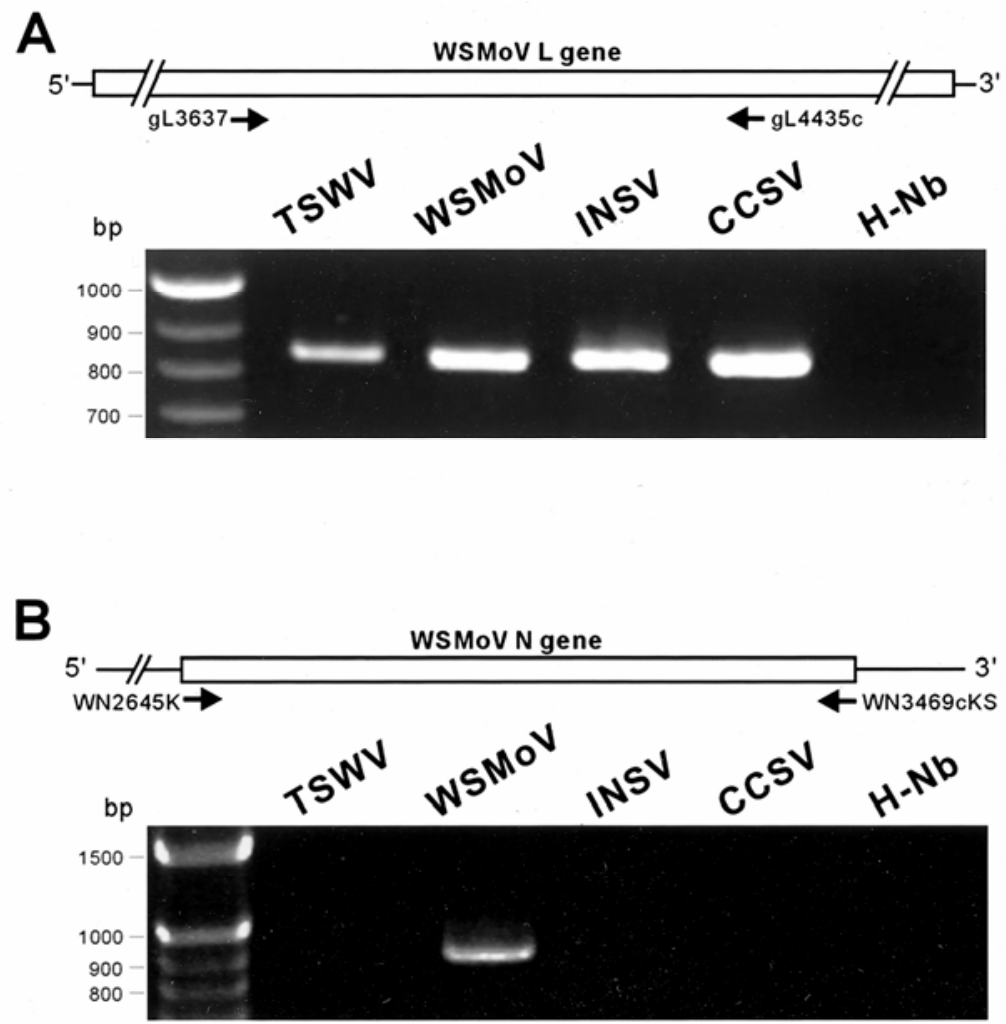

Fig. 4. DNA products of reverse transcription-polymerase chain reaction of RNA of Tomato spotted wilt virus (TSWV), Watermelon silver mottle virus (WSMoV), Impatiens necrotic spot virus (INSV), and Calla lily chlorotic spot virus (CCSV) using A, degenerate primer pairs designed from the conserved regions of the L RNA of tospovirus and $\mathbf{B}$, primers specific for the $\mathrm{N}$ gene of WSMoV. DNA ladder markers (100 bp) are on the left. 


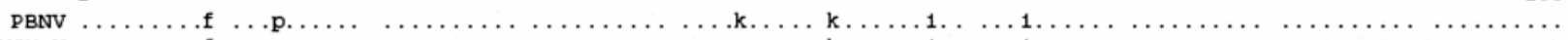

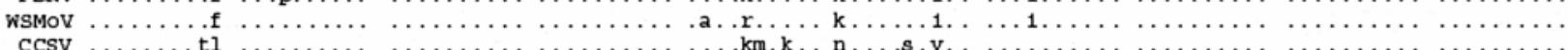

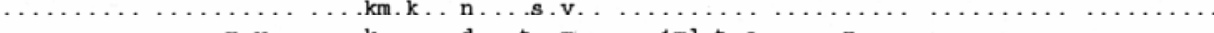

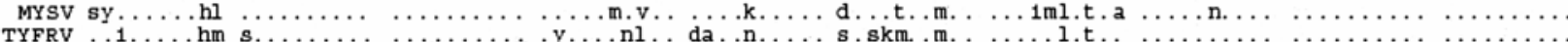

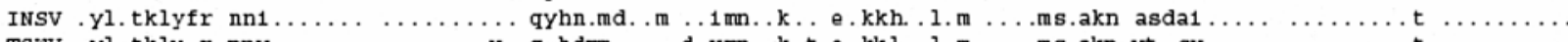

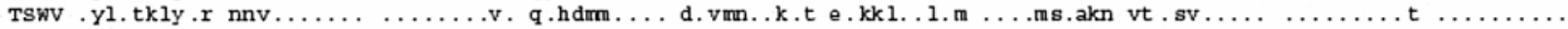
Consensus TPMKVRYGY- KTTTVLKSKK VSEELYDLIK EFNKITEIDL ELSE-LGRGL -GNRVTF-QL LEPVLMKSRT NAGNTDFLVS VPEKMQRTKM DREIYLMSMK

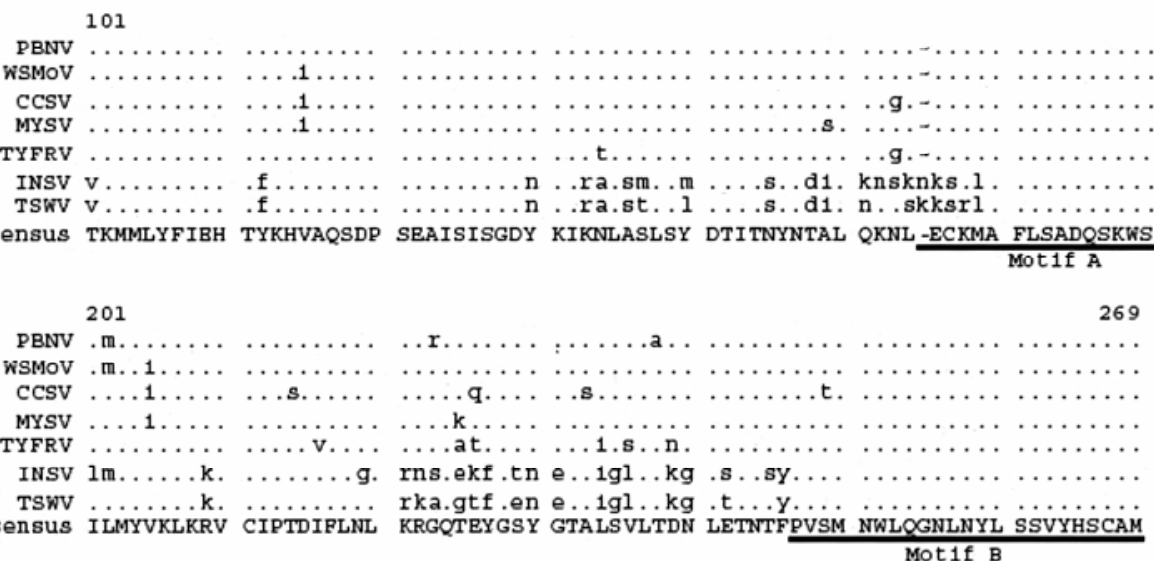

Fig. 5. Comparison of deduced amino acid sequence of the conserved region on L protein of Calla lily chlorotic spot virus (CCSV) with those of Peanut bud necrosis virus (PBNV, AF025538), Watermelon silver mottle virus (WSMoV, AF133128), Melon yellow spot virus (MYSV, AB061774), Tomato yellow fruit ring virus (TYFRV, AJ493271), Impatiens necrotic spot virus (INSV, X93218), and Tomato spotted wilt virus (TSWV, D10066). Dots indicate the consensus amino acids, diagonal dashes indicate no amino acids in the fragments, and hyphens in the consensus sequences indicate the residues that differ. The motifs $\mathrm{A}$ and $\mathrm{B}$ of RNA-dependent RNA polymerase are underlined.

Table 1. Comparisons of the conserved region of L protein of Calla lily chlorotic spot virus (CCSV) with those of other tospoviruses ${ }^{\mathrm{a}}$

\begin{tabular}{lcc}
\hline Virus & Identity $(\boldsymbol{\%})$ & Similarity $(\boldsymbol{\%})$ \\
\hline WSMoV & 92.88 & 96.63 \\
PBNV & 91.39 & 95.51 \\
MYSV & 89.51 & 94.01 \\
TYFRV & 87.27 & 92.51 \\
TSWV & 67.04 & 77.15 \\
INSV & 65.17 & 76.40 \\
\hline
\end{tabular}

${ }^{a}$ Sequence comparisons were conducted with the Bestfit program of the SeqWeb sequence analysis system. TSWV = Tomato spotted wilt virus (D10066); INSV = Impatiens necrotic spot virus $(\mathrm{X} 93218) ; \mathrm{WSMoV}=$ Watermelon silver mottle virus (AF133128); $\mathrm{PBNV}=$ Peanut bud necrosis virus (AF025538); TYFRV = Tomato yellow fruit ring virus (AJ493271); MYSV = Melon yellow spot virus (AB061774).

fragment was present in RT-PCR from the RNA extracted from a WSMoV-infected plant, however (Fig. 4B).

\section{DISCUSSION}

Our survey results show that one or more viruses, including CarMV, CMV, DsMV, ZaMV, ZaMMV, and TuMV, may cause infection in individual calla lily plants. During the surveys conducted, we isolated and identified a tospovirus, Calla lily chlorotic spot virus (CCSV), that induces chlorosis in calla lilies. The virus is transmitted by Thrips palmi. Virions of CCSV measure 75 to $105 \mathrm{~nm}$ in diameter. Virion particles possess membranes. In ELISA, CCSV reacts with the antiserum prepared to WSMoV but not with the an- tisera to TSWV, INSV, or PCFV. The CCSV antigen also reacts weakly with the antiserum prepared to $\mathrm{WSMoV}$ in western blot assay. The results also show that the NPs are similar in size for both viruses. RT-PCR in current studies showed that the conserved regions of the $\mathrm{L}$ genes among tospoviruses are present in CCSV. All results from our studies indicate that CCSV is a member of the genus Tospovirus (10).

Classification of tospoviruses is difficult because of high variability and wide host range of the causal agents. Before the establishment of a definitive taxonomic position in the genus Tospovirus, a provisional species is tentatively assigned to CCSV. Based on the reactivities using polyclonal antibodies in current studies, CCSV is serologically related to WSMoV. Monoclonal antibodies that react to all members of WSMoV subgroup including WSMoV, PBNV, WBNV, and gloxinia HT-1 (1), however, did not react with CCSV (data not presented). The WSMoV N gene-specific primers WN2645K and WN3469cKS, used in this investigation, and other primers specific to WSMoV $\mathrm{N}$ gene (25), also failed to amplify the $\mathrm{N}$ gene of CCSV (data not presented). Nevertheless, a DNA probe derived from CCSV $\mathrm{N}$ gene generated a weak signal with WSMoV RNA (16). A strong signal was obtained with homologous CCSV RNA, and no signals were observed with RNA prepared from TSWV- or INSV-infected tissue (16). These results imply that a low sequence homology exists between $\mathrm{N}$ genes of CCSV and WSMoV. Results also suggest that CCSV nucleocapsid protein shares fewer common epitopes with other members of WSMoV subgroup. Without specific information on $\mathrm{N}$ gene sequence, it is difficult to establish a definitive position for CCSV in the genus Tospovirus (21).

Although calla lilies are typically grown outdoors, the major flowering season occurs in greenhouses from early winter through late spring. Our surveys show that field-grown calla lilies are vulnerable to many viruses in open environments where many other horticultural crops are grown. Management of diseases caused by viruses, especially those transmitted by insects, is difficult in areas where intensive farming is practiced. The identification of CCSV, a new member of Tospovirus, adds a new concern to the production of healthy calla lilies since the virus is transmitted by T. palmi. The thrips is a vector of viruses belonging to WSMoV subgroup. It is abundant in Asia and Hawaii, and has been reported to occur in Florida (19). It is worth noting that the recurrence of TSWV and the outbreak of INSV in ornamental crops in the United States during the 1990s were correlated with high populations of Frankliniella occidentalis.

\section{LITERATURE CITED}

1. Adam, G., Peters, D., and Goldbach, R. W 1996. Serological comparison of tospovirus isolates using polyclonal and monoclonal antibodies. Acta Hortic. 431:135-158.

2. Chang, Y.-C., Chen, Y.-L., and Chung, F.-C. 2001. Mosaic disease of calla lily caused by a new potyvirus in Taiwan. Plant Dis. 85:1289.

3. Chen, C. C., Chang, C. A., Tsai, H. T., Cheng, Y. H., Chao, C. H., and Yeh, S. D. 2000. First detection of turnip mosaic virus on calla lily. Plant Pathol. Bull. 9:184. 
4. Chen, C. C., Chao, C. H., Chen, C. C., Yeh, S. D., Tsai, H. T., and Chang, C. A. 2003. Identification of Turnip mosaic virus isolates causing yellow stripe and spot on calla lily. Plant Dis. 87:901-905.

5. Chen, C. C., Ko, W. F., Jan, F. J., Lin, C. Y., and Hsu, H. T. 2002. Characterization of Carnation mottle carmovirus isolated from calla lily (Zantedeschia spp.). Plant Pathol. Bull. 11:242-243.

6. Chen, T.-C. 2001. Broad-spectrum resistance to tospoviruses in transgenic Nicotiana benthamiana plants carrying the conserved RNA polymerase motifs of Watermelon silver mottle virus and expression of its individual genes using the Zucchini yellow mosaic virus vector. Ph.D. diss. Department of Plant Pathology, National Chung Hsing University, Taichung, Taiwan.

7. Chu, F.-H., Chao, C.-H., Chung, M.-H., Chen, C.-C., and Yeh, S.-D. 2001. Completion of the genome sequence of Watermelon silver mottle virus and utilization of degenerate primers for detecting tospoviruses in five serogroups. Phytopathology 91:361-368.

8. Chu, F.-H., Chao, C.-H., Peng, Y.-C., Lin, S.-S., Chen, C.-C., and Yeh, S.-D. 2001. Serological and molecular characterization of Peanut chlorotic fan-spot virus, a new species of the genus Tospovirus. Phytopathology 91:856-863.

9. de Haan, P., Kormelink, R., Resende, R. de O., van Poelwijk, F., Peters, D., and Goldbach, R. 1991. Tomato spotted wilt virus L RNA encodes a putative RNA polymerase. J. Gen. Virol. 71:2207-2216.

10. Goldbach, R., and Kuo, G. 1996. Introduction. Acta Hortic. 431:21-26.

11. Gooderham, K. 1984. Transfer techniques in protein blotting. Pages $165-178$ in: Methods in Molecular Biology, Vol. 1. J. M. Walker, ed. Humana Press, Clifton, NJ.

12. Gowda, S., Satyanarayana, T., Naidu, R. A., Mushegian, A., Dawson, W. O., and Reddy, D. V. R. 1998. Characterization of the large (L) RNA of peanut bud necrosis tospovirus. Arch. Virol. 143:2381-2390.

13. Huang, C. H., and Chang, Y. C. 2002. Zantedeschia mild mosaic virus, a new potyvirus infecting callas. Plant Pathol. Bull. 11:250.

14. Law, M. D., and Moyer, J. W. 1990. A tomato spotted wilt-like virus with a serologically distinct N protein. J. Gen. Virol. 71:933-938.

15. Lesemann, D.-E., and Winter, S. 2002. Konjac mosaic virus, Dasheen mosaic virus and unknown potyviruses infecting Zantedeschia spp. and other cultivated Araceae. Acta Hortic. 568:135-141.

16. Lin, Y. H., Chen, T. C., Chung, M. H., Yeh, S. D., Hsu, H. T., and Chen, C. C. Sequence analysis of Calla lily chlorotic spot virus, a new tospovirus. Acta. Hortic. In press.

17. Pang, S.-Z., Slightom, J. L., and Gonsalves, D. 1993. The biological properties of a distinct tospovirus and sequence analysis of its S RNA. Phytopathology 83:728-733.

18. Pham, K., Langeveld, S. A., Lemmers, M. E. C., and Derks, A. F. L. M. 2002. Detection and identification of potyviruses in Zantedeschia. Acta Hortic. 568:143-148.

19. Tsai, J. H., Yue, B., Webb, S., Funderburk, J. E., and Hsu, H. T. 1995. Effects of host plant and temperature on growth and replication of Thrips palmi (Thysanoptera: Thripidae). Environ. Entomol. 24:589-603.

20. van Poelwijk, F., Prins, M., and Goldbach, R.
1997. Completion of the impatiens necrotic spot virus genome sequence and genetic comparison of the $\mathrm{L}$ proteins within the family Bunyaviridae. J. Gen. Virol. 78:543-546.

21. van Regenmortel, M. H., Fauquet, C. M. Bishop, D. H. L., Carsterns, E. B., Estes, M K., Lemon, S. M., Maniloff, J., Mayo, M. A., McGeoch, D. J., Pringle, C. R., and Wickner, R. B. 2000. Virus Taxonomy: Classification and Nomenclature of Viruses. Seventh Report of the International Committee on Taxonomy of Viruses. Academic Press, New York. p. 599.

22. Wang, M., and Gonsalves, D. 1990. ELISA detection of various tomato spotted wilt virus isolates using specific antisera to structural proteins of the virus. Plant Dis. 74:154-158.

23. Yeh, S. D., Chao, C. H., Cheng, Y. H., and Chen, C. C. 1996. Serological comparison of four distinct tospoviruses by polyclonal antibodies to purified nucleocapsid proteins. Acta Hortic. 431:122-134.

24. Yeh, S. D., Lin, Y. C., Cheng, Y. H., Jih, C. L., Chen, M. J., and Chen, C. C. 1992. Identification of tomato spotted wilt-like virus infecting watermelon in Taiwan. Plant Dis. 76:835-840.

25. Yeh, S. D., Sun, I. J., Ho, H. M., and Chang, T. F. 1996. Molecular cloning and nucleotide sequence analysis of the S RNA of Watermelon silver mottle tospovirus. Acta Hortic. 431:244260.

26. Zettler, F. W., and Hartman, R. D. 1995. Virus diseases of major ornamental cropsDieffenbachia, Caladium, and Zantedeschia. Pages 464-470 in: Virus-like Diseases of Bulb and Flower Crops. G. Loebenstein, R. H. Lawson, and A. A. Brunt, eds. John Wiley \& Sons Inc., Chichester, UK. 